2013

\title{
Due Process in Islamic Criminal Law
}

Sadiq Reza

New York Law School

Follow this and additional works at: http://digitalcommons.nyls.edu/fac_articles_chapters

Part of the Criminal Law Commons, Criminal Procedure Commons, and the International Law Commons

\section{Recommended Citation}

46 Geo. Wash. Int'1 L. Rev. 1 (2013-2014)

This Article is brought to you for free and open access by the Faculty Scholarship at DigitalCommons@NYLS. It has been accepted for inclusion in Articles \& Chapters by an authorized administrator of DigitalCommons@NYLS. 


\title{
DUE PROCESS IN ISLAMIC CRIMINAL LAW
}

\author{
SADIQ ReZA*
}

\begin{abstract}
Rules and principles of due process in criminal law-how to, and how not to, investigate crime and criminal suspects, prosecute the accused, adjudicate criminal cases, and punish the convicted-appear in the traditional sources of Islamic lav: the Quran, the Sunna, and classical jurisprudence. But few of these miles and principles are followed in the modern-day practice of Islamic criminal law. Rather, states that claim to practice Islamic criminal law today mostly follow laws and practices of criminal procedure that were adopted from European nations in the twentieth century, without reference to the constraints and protections of Islamic law itself. To enforce Islam's criminal prohibitions and punishments without recognizing and heeding its own procedural rules and principles is to prosecute and punish unjustly. What constitutes criminal due process from an Islamic perspective must therefore be identified, articulated, and enforced. The result would be greater compliance with both Islamic norms and international standards of human rights.
\end{abstract}

\section{INTRODUCTION}

Some of the most visible and controversial applications of Islamic law today occur in criminal law. Reports of prosecutions and punishments under Islamic law (sharia) regularly attract worldwide attention, and justifiable condemnation, from Muslims and non-Muslims alike. ${ }^{1}$ Only about a dozen of the world's forty-four Muslim-majority countries formally practice Islamic criminal law. In most of those countries that practice began only recently as part of state "Islamization" programs undertaken over the past thirty to forty years; but criminal law has been a central aspect of those programs. ${ }^{2}$ In current Islamization efforts too, the institution of so-

* Professor, New York Law School. J.D. 1991, Harvard Law School; A.B. 1986, Princeton University.

1. See, e.g., Robert F. Worth, Crime (Sex) and Punishment (Stoning), N.Y. T1MEs, Aug. 22, 2010, at WK1 (discussing stoning for adultery in the context of recent cases in Afghanistan and Iran).

2. See Rudolph Peters, Crime and Punishment in Islamic Law 142-45, 153 (2005) ("Islamic criminal law . . . has a highly symbolic value and its introduction is regarded by many Muslims as the litmus test of real Islamisation of the legal system."). 
called Islamic criminal prosecutions and punishments is routinely a key component. ${ }^{3}$

The list of crimes and punishments that shape the modern-day practice of Islamic criminal law-the framework of a sharia penal code-was established over a thousand years ago. This framework consists of categories of forbidden acts and accompanying penalties that early Muslim scholars derived from Islam's sacred texts and primary sources of law-the Quran and the Sunna (Traditions) - through standard jurisprudential methods. Early scholars also set out rules of court procedure, such as the order of proof, witness qualifications, and other evidentiary burdens. But the scholars never set out a corresponding set of rules that govern officials in investigating suspected offenders and prosecuting them in terms of limitations that bind the state and rights that accrue to suspects and defendants in the process-i.e., a framework of protections for individuals in the criminal process, such as those in the Bill of Rights to the U.S. Constitution. Nor has such a framework been established in modern times. As a result, modern-day systems of Islamic criminal law enforce criminal prohibitions and punishments originating from Islamic doctrines that are up to fourteen hundred years old, but operate mostly under codes and practices of procedure that were adopted from European nations in the twentieth century.

Thus, states that enforce sharia criminal prohibitions and punishments today do so mostly according to procedural rules and principles that did not originate to govern Islamic criminal law. This makes for a significant anomaly in the contemporary practice of Islamic criminal law (and, accordingly, in modern Islamization efforts more broadly), an anomaly of practical as well as theoretical dimensions. For although there is no formal framework or system of criminal procedure in Islamic legal theory, the Quran does contain rules and principles that address criminal procedure in the modern sense-namely: how to, and how not to, investigate crime and criminal suspects, prosecute accused offenders, adjudicate criminal cases, and punish convicted offenders. ${ }^{4}$ So too, indeed even more so, do the Traditions, which compile the statements and

3. See, e.g., Tim Lindsey \& Jeremy Kingsley, Talking in Code: Legal Islamisation in Indonesia and the MMI Shari'a Criminal Code, in The LAW Applied: Contextualizing the IsLamic SHARI'A 295, 301-02 (Peri Bearman et al. eds., 2008) (discussing such efforts in Indonesia and Malaysia).

4. The topic of punishment straddles the substance/procedure divide in criminal law in all legal systems, at least in contemporary Western scholarship. For instance, what specific penalty a given crime carries is seen as a matter of substance; how to reach that 
practices of the Prophet Muhammad (the Prophet) and his earliest followers (the Companions), and thus constitute the most authoritative body of precedents in Islamic law. These rules and principles have been recognized and restated by Muslim legal scholars from classical times to today, often in the very same texts in which the substantive criminal prohibitions and penalties are discussed. As explained below, some of these rules and principles limit the power of the state in enforcing Islam's criminal prohibitions. Others provide what we see today as guarantees of individual liberties in the criminal process. Still others appear to serve different purposes, perhaps effectuating divine goals that are not immediately apparent, or at least that are not easily placed on the modern/secular spectrum of the state versus the individual. But few of these rules or principles appear to be recognized or followed in the modern-day practice of Islamic criminal law.

To enforce Islam's criminal prohibitions and punishments without recognizing and heeding its accompanying procedural rules and principles, whatever their content and import, is to practice Islamic criminal law inaccurately and incompletely-indeed, "unIslamically." More concretely, doing so arguably results in injustice from an Islamic point of view-be it injustice to the individual, to the state, to the community, or in God's eyes alone. "Islamic" criminal law cannot, in other words, consist simply of imposing and enforcing the criminal prohibitions and penalties that appear in the sacred texts. It must also consist of how those prohibitions and penalties are enforced-what rules and principles govern that enforcement. What constitutes criminal due process from an Islamic perspective-i.e., the Islamic framework of human rights in criminal practice-must therefore be identified and articulated.

This Article frames and begins the task of identifying those rules and principles. And the inquiry aims at more than just regulating the practice of Islamic criminal law-"Islamizing" that practice, if you will. There is much to be learned about Islamic law in its rules and principles of criminal due process. And there is much to be learned from those rules and principles, for purposes of comparative-law study. The inquiry also identifies common ground between opposing camps in current-day battles over the role and content of Islamic law in modern states: Muslim "traditionalists" and "progressives" alike-both those who seek to reinstate the earliest and purest principles and practices of Islam, and those who

penalty and whether to mete it out-i.e., rules of conviction and sentencing-are seen as matters of procedure. 
seek to reinterpret the sacred texts for modern realities and sensibilities-should be gratified to find the essentials of human rights in the Islamic criminal process spelled out. At the very least, those who urge the practice of Islamic criminal law cannot easily dismiss procedural rules and principles that have been articulated to govern its enforcement, while those who oppose that practice can at least insist that those rules and principles be honored.

There are thus very good reasons to identify the essentials of criminal due process in Islam. This Article makes the case for this inquiry and begins it. Part I briefly explains the nature of "Islamic" criminal law. Part II expands on the conceptual claims above to frame more fully the inquiry into a corresponding "Islamic" code of criminal procedure. It also identifies a methodology and suggests a doctrinal framework for one. Part III presents four rules or principles that result from the inquiry, as both illustrative examples and preliminary findings. Part IV offers observations on these findings and the inquiry generally.

\section{I. "Islamic" Criminal Law Today}

Laws to enforce "Islamic" crimes and punishments have been enacted in several Muslim-majority countries over the past thirtyfive years-Libya (beginning in 1972), the United Arab Emirates (1978), Pakistan (1979), Iran (1982), the Sudan (1983), and the states of northern Nigeria (2000-2002) and passed but not enacted in two Muslim-controlled states of Malaysia (1993 and 2002). ${ }^{5}$ Islamic criminal law is also applied by the Islamic courts that have arisen to govern much of Somalia over the past decade, first by the Islamic Courts Union and now by successor groups such as the Shabab. ${ }^{6}$ It has always been applied in Saudi Arabia, Qatar, and Yemen, areas that were more or less unaffected by the wave of Western-style codification that swept through the Muslim world in the nineteenth and twentieth centuries. ${ }^{7}$ And it can be applied in countries in which the law allows for its ad hoc application. ${ }^{8}$ One example of such ad hoc application is Afghanistan, where the Quranic crime of apostasy is not listed in the penal code, but never-

5. See Peters, supra note 2, at 153-55, 161, 164, 169; Lindsey \& Kingsley, supra note 3, at 301-02 (discussing such efforts in Indonesia and Malaysia).

6. See U.S. Dep't State, Somalia 11 (2011), available at http://www.state.gov/docu ments/organization/160144.pdf; The Supreme Islamic Courts Union / al-Ittihad Mahakem alIslamiya (ICU), GlobalSecurity.org (Oct. 5, 2013, 12:36 PM), http://www.globalsecurity .org/military/world/para/icu.htm.

7. Peters, supra note 2 , at 143.

8. See id. at 147. 
theless, prosecutions for that crime are occasionally threatened and arguably lawful under a constitutional provision that authorizes following Islamic law in matters not addressed by the constitution or other laws. ${ }^{9}$ Another example is the small island nation of the Maldives, which, aided by a similar catchall provision in its penal code, completed in 2006 (with the assistance of an American scholar of criminal law) a new draft penal code that includes specific Islamic crimes and punishments. ${ }^{10}$

The substantive scope of Islamic criminal law-what conduct is considered criminal, and what possible punishments follow-is relatively well established in Islamic jurisprudence. On the basis of the Quran and the Sunna (Traditions), which are the primary sources of Islamic law, classical Muslim legal scholars identified what amount to three distinct categories of crime: (1) the handful of "fixed" crimes $(h u d u d)$, which call for the harsh physical punishments for which Islamic criminal law is best known; (2) bodilyinjury offenses (jinayat), which call for "just retribution" (qisas) or monetary compensation, according to the victim's wishes; and (3) other crimes, which constitute the vast majority of possible offenses, are unspecified, and call for "corrective" punishment (ta'zir) in the ruler's discretion. ${ }^{11}$ One or another version of these categories, particularly the hudud category, provides the substantive framework for modern-day Islamic criminal law and practice. ${ }^{12}$ The Quran and Traditions also give rules about the evidence required to prove crimes, particularly the required number and qualifications of witnesses, and again particularly with respect to hudud offenses. ${ }^{13}$ Classical scholars have developed a substantial body of jurisprudence on this topic as well. ${ }^{14}$ These rules too, to varying degrees, apply in modern-day Islamic criminal practice.

9. See The Constitution of AfG. Jan. 3, 2004, art. 130; see, e.g., Ray Rivera, Afghan Officials Say Jailed Christian Convert is Free, N.Y. Times, Feb. 26, 2011, at A6; Christian Convert Gets Asylum, L.A. Times, Mar. 30, 2006, at A24.

10. See Paul Robinson et al., Codifying Shari'a: International Norms, Legality and the Freedom to Invent New Forms, 2 J. CoMP. L. 1, 3, 4 (2007).

11. Mohamed S. El-Awa, Punishment in Islamic Law: A Comparative Study 1-2 (1982). Scholars count between four and seven hudud crimes, with a majority view of six: theft, brigandage or mayhem, adultery or fornication, false accusation of adultery or fornication, wine drinking, and apostasy. Id. at 2. The punishments for these crimes include flogging, amputation, and death by crucifixion or stoning. See id. at 2-3, 10-12, 15-17, 20, $45-46,50$.

12. Peters, supra note 2, at 153-73.

13. See Mohammed Selim El-Awa, Confession and Other Methods of Evidence in Islamic Procedural Jurisprudence, in Criminal Justice in Islam: Judicial Procedure in the Shari'a 111, 117-29 (Muhammad Abdel Haleem et al. eds., 2003).

14. See, e.g., id. 
But a system of criminal procedure in its modern sense-rules that govern how crime should be investigated and prosecuted, what limitations bind the state, and what rights accrue to suspects and defendants in the process-has never been fully articulated in Islamic legal theory. ${ }^{15}$ The Quran and the Sunna are traditionally seen as saying little directly on the subject, and pre-modern jurists developed no comprehensive theory or framework of criminal procedure-certainly nothing akin to the categories of substantive crime. Moreover, in pre-modern practice-at least from what we know of the Arab-Ottoman lands-matters of criminal procedure were governed not by jurists and religious doctrine, but by executive authorities and the rules they promulgated. ${ }^{16}$ In modern times, some Muslim thinkers have addressed criminal procedure from an Islamic jurisprudential perspective, occasionally identifying pertinent Islamic principles, but more often urging conformity with contemporary standards of international human rights in the criminal process, and in either case with few specifics. ${ }^{17}$ There is thus no template of procedural rules similar to the categories of substantive crime (and rules of evidence) in formal Islamic jurisprudence to govern the modern state practice of Islamic criminal law.

As a result, states that claim to practice Islamic criminal law today instead do so mostly according to the rules and principles of the

15. See, e.g., Abdullahi Ahmed An-Na'im, Toward an Islamic Reformation: Givil Liberties, Human Rights, and International Law 124 (1990) (arguing that because early Muslim jurists "were naturally unaware of the currently much-appreciated need to regulate and control the powers of arrest, search and seizure and so forth," Islamic law "historical[ly] ... had very little to say on these [and other] vital questions of practical law enforcement").

16. See Sadiq Reza, Islam's Fourth Amendment: Search and Seizure in Islamic Doctrine and Muslim Practice, 40 Geo. J. INT'L L. 703, 709 (2009). Indeed, historical studies consistently find that criminal law in the pre-modern Muslim world was-at least in the well-studied Arab-Ottoman regions-primarily investigated and prosecuted not under the authority (or in the courts) of Islamic-law judges ( qadis), who were the guardians of the classical jurisprudence, but in the quasi-courts and administrative tribunals of governors, police officers, and other executive authorities. See id. at 712. Records of proceedings in qadi courts have been unearthed from various periods and places of the pre-modern Muslim world, but records of these executive proceedings and dispositions are few or nonexistent. Moreover, all indications are that executive authorities enforced criminal law largely unconstrained by the jurisprudential doctrines that bound qadis-so it is unlikely they would have felt bound by any procedural rules that did exist. See id. at 769-70.

17. See, e.g., An-Na'im, supra note 15, at 124; Mashood A. Baderin, International Human Rights and Islamic Law 89-90, 114-18 (2003); Muhammad Asad, The Principles OF State and Government in Islam 84-86 (1980) (arguing that a true Islamic state must protect, inter alia, citizens' "dignity and honor and the privacy of their homes," and calling for constitutional enactments that guarantee these protections and prohibit governments from violating them). 
Western-style constitutions and codes of criminal procedure imported in the nineteenth and twentieth centuries. Pakistan, for instance, applies the same body of procedural rules to enforce the "Islamic" criminal prohibitions implemented in 1979 that it applies to "non-Islamic" criminal proceedings: a code of criminal procedure enacted in 1898 by the British-appointed Indian Law Commission. ${ }^{18}$ The United Arab Emirates (UAE), which included Islamic criminal prohibitions in its first unified criminal code in 1987, enacted five years later a code of criminal procedure much like that of Egypt - modeled along French lines and devoid of "Islamic" procedural considerations. ${ }^{19}$ In the Maldives, the Islamic penal code that Professor Robinson helped draft five years ago includes citations to the Quran and Sunna to demonstrate its grounding in the sharia, but it is still pending before Parliament. Yet Islamic criminal prosecutions occur in the Maldives on the same legal grounds as they do in Afghanistan: through constitutional provisions that declare Islam the religion of the state and the basis of its laws (Articles 2, 10,19) and allow uncodified sharia principles to supplement, and even trump, other legislation (Articles 16, 19, $142,274) .{ }^{20}$ In both countries, these prosecutions are governed by the same sharia-free procedural codes that govern non-sharia criminal enforcement: in the Maldives, a 2010 Judicature Act, and in Afghanistan, a 2004 Interim Criminal Procedure Code. ${ }^{21}$

To be sure, some modern states that enforce Islamic criminal prohibitions have adopted or referenced at least some "Islamic" rules of procedure to govern that enforcement. The opening article of Saudi Arabia's criminal procedure code, enacted in 2002, states that courts hearing criminal cases must apply "Shari'ah principles, as derived from the Qur'an and Sunnah," along with regulations that comply with the Code and do not contradict "the provisions of the Qur'an and Sunnah."22 But what "sharia" rules or provisions are intended is not explained, and the Code provisions

18. See M. Farani, The Criminal Procedure Code, 1898, 40 (2004). Indeed, each of the four 1979 "hudud ordinances"-criminalizing illicit sex, false accusation of the same, theft, and intoxicants-states expressly that the 1898 code governs proceedings under the new legislation, with only minor technical adjustments.

19. See Butti Sultan Butti Ali al-Muhairi, The Islamisation of Laws in the UAE: The Case of the Penal Code, 11 AraB L.Q. 350, 356, 358 (1996).

20. Constitution of the Republic of Maldives Aug. 7, 2008; The Constitution of AfG. Jan. 3, 2004, art. 130.

21. See John Jupp, Legal Transplants as Solutions for Post-Intervention Criminal Law Reform: Afghanistan's Interim Criminal Procedure Code 2004, 61 Ам. J. СомP. L. 51, 74-76 (2013).

22. Law of Criminal Procedure, Umm al-Qura 3867, art. 1 (2001) (Saudi Arabia). 
themselves do not reflect a "sharia" provenance. ${ }^{23}$ Iran's 1999 Code of Criminal Procedure, on the other hand, is replete with references to the sharia and Islamic norms, and many of its provisions are tailored expressly for investigating and prosecuting "Islamic" crimes. ${ }^{24}$ The Islamic provenance of many of its provisions is obvious, and at least one of the rules to be discussed below in this Article is set out: the prohibition against investigating "private" acts of immorality. ${ }^{25}$ That rule does not appear to be in the criminal procedure codes that the states of northern Nigeria adopted soon after they began implementing Islamic criminal law in the year 2000-but that did not stop the appeals court of one of those states from invoking the rule as a ground for reversing the adultery conviction of Safiyatu Hussaini in 2001.26 Instead, the court cited Quranic verses, Traditions, and scholarly opinions in support of that rule and result, as courts are authorized to do by catchall provisions of other codes that allow uncodified sharia principles to be invoked. ${ }^{27}$ In the Sudan, Islamic rules and principles of criminal procedure appear in a variety of legal sourcesa Penal Code, a Criminal Procedure Act, a Judicature Act, and

23. See id. There are minor exceptions-for instance, the provisions on searching homes, which specify that a female must accompany the searching officers if a female suspect is the only occupant of the home at the time of the search, id. art. 52 (implying a search of the suspect/arrestee, since under art. 42 only female officers may search female arrestees incident to arrest), and that any female occupants who are not to be searched must be given the opportunity to don their veils or leave the home, id. art. 53 .

24. See Qanun-i A'yin-i Dadrisiyih Dadgahhayih Umumi va Inqilab dar Umur-i Kayfari [Criminal Procedure Code for Public and Revolutionary Courts] Tehran 1378 [1999] (Iran), translated in English Translation of the Islamic Republic of Iran's Criminal Code of Procedure for Public and Revolutionary Courts, Iran Hum. RTs. Documentation Center, http:// www.iranhrdc.org/english/english/human-rights-documents/iranian-codes/1000000026english-translation-of-the-islamic-republic-of-irans-criminal-code-of-procedure-for-publicand-revolutionary-courts.html (last visited Feb. 2, 2014).

25. See id. art. 43 (prohibiting investigating crimes of "unchaste behavior" that are not "obvious"); see also id. arts. 2-4 (distinguishing between crimes that implicate public rights and those that implicate private rights), 6(1) (allowing prosecution to be suspended upon plaintiff's forgiveness in qualifying crimes), 8 (suspending sentence upon same), 155 (witness qualifications).

26. See, e.g., Ctr. for Islamic legal Studies, Harmonised Sharia Criminal Procedure Code Based on the Harmonised Sharia Penal Code, in 4 Sharia Implementation in Northern Nigeria 1996-2006: A Sourcebook 221, 222 (Philip Ostien ed., 2007); see also Hussaini v. State, [2001] (Nigeria), translated in Proceedings and Judgment in the Sharia Court of Appeal, 5 Sharia Implementation in Northern Nigeria 1996-2006: A Sourcebook 26, 47-49 (Philip Ostien ed., 2007).

27. Philip Ostien, Introduction to Chapter 5, in 4 Sharia IMPLEMENTATION IN NORTHERN Nigeria 1996-2006: A SOURCEBOOK, supra note 26 at 188-90. 
periodic judicial circulars-and uncodified sources can also be invoked. ${ }^{28}$

There is thus little clarity, and even less uniformity, in the "Islamic" rules of criminal procedure that modern states refer to and apply when practicing Islamic criminal law.

\section{The Case for "Islamic" Criminal Procedure}

It is no aberration in world history that pre-modern Muslim jurists did not provide a template for criminal procedure; detailed rules for the criminal process-and certainly rules that specify limitations on state power and protections for suspects and defendants-are a relatively recent phenomenon in the West itself. ${ }^{29}$ The result of the absence of such a body of rules in pre-modern Islamic jurisprudence, however, coupled with the absence of a modern articulation of one, is that the states of the modern Muslim world that practice Islamic criminal law do so in the absence of an established system of "Islamic" criminal procedure-including rules that limit state power and provide rights and protections for suspects and defendants-deriving from Islam and corresponding with the substance and theory of Islamic crimes and punishments.

At first blush, this might not appear to pose a problem. The imported constitutions and codes contain, as noted above, some version of the limitations and protections that are considered fundamental in the criminal process today-requiring warrants for searches and seizures, guaranteeing notice of criminal charges and the opportunity to mount a defense, providing a right to counsel, guaranteeing a fair and public trial, and so forth. ${ }^{30}$ These rules generally apply to investigations and prosecutions of Islamic crimes as well as those of "non-Islamic" crimes. ${ }^{31}$ Moreover, most of these states are also parties to international covenants that mandate these limitations and protections, such as the 1966 International Covenant on Civil and Political Rights and the 1984 Convention

28. See Aharon Layish \& Gabriel R. Warburg, The Reinstatement of Islamic Law in Sudan Under Numayr: An Evaluation of a Legal Experiment in the Light of its HisTORICAL CONTEXT, MeTHOdOLOGY, AND RePERCUSSIONS 77, 98-115, 127-28, 174-75 (2002).

29. It was not until the late eighteenth century that, for instance, England settled on the beyond-a-reasonable-doubt standard of proof in criminal trials, JOHN H. LANGBEIN, THE Origins of Adversary Criminal Trial 22-23 (2003), continental Europe fully eliminated torture as a routine investigative method, JoHn H. LANGBEIN, TORTURE AND THE LAw OF Proof 3 (2006), and the United States enumerated its list of protections for criminal suspects and defendants in the Bill of Rights, U.S. CoNST. amends. IV, V, VI, VII (which France followed soon thereafter in the Declaration of the Rights of Man).

30. See FARANI, supra note 18 , at 38 .

31. See id. 
Against Torture and Other Cruel, Inhuman or Degrading Treatment. $^{32}$ Muslim-majority countries have also adopted "Islamic" declarations of human rights, such as the 1981 Universal Islamic Declaration of Human Rights (UIDHR), the 1990 Cairo Declaration on Human Rights in Islam, and the 1994 Arab Charter on Human Rights (revised in 2004). ${ }^{33}$ All of these declarations include some version of the litany of modern rules of criminal due process; all of them assert that these rules are compatible with Islamic law, indeed grounded in it. ${ }^{34}$

Even without these laws and treaties, one might ask: what need is there for a code of "Islamic" criminal procedure, if God did not see fit to specify one in the Quran, the Prophet and his Companions did not provide one in the Sunna, classical scholars did not articulate one in their jurisprudence, pre-modern Muslim states apparently managed fine without one, and modern states now have Western rules and Islamic restatements to rely on?

I suggest three reasons why the practice of Islamic criminal law today needs an accompanying set of "Islamic" rules of criminal procedure drawn from Islamic law and principles. First, criminal procedure rules of Western origin (i.e., of non-Islamic provenance) are vulnerable to attack or dismissal as inauthentic, illegitimate, or simply irrelevant to the practice of Islamic criminal law. ${ }^{35}$ The enforcement of these rules, and perhaps even their continued exis-

32. See 4 International Covenant on Civil and Political Rights, UnIted Nations Treaty Collection, http://treaties.un.org/pages/viewdetails.aspx?src=treaty\&mtdsg_no=iv-4\& chapter $=4 \&$ lang=en (last visited Nov. 19, 2013) (Status of International Covenant on Civil and Political Rights); Convention Against Torture and Other Cruel, Inhuman or Degrading Treatment or Punishment, UnITEd NATIONS TREATY Collection, http://treaties.un.org/Pages/ ViewDetails.aspx?mtdsg_no=IV-9\&chapter=4\&lang=en (last visited Nov. 19, 2013) (status of Convention Against Torture and Other Cruel, Inhuman or Degrading Treatment).

33. See Islamic Council of Eur., Universal Islamic Declaration of Human Rights (Sept. 19, 1981), available at http://www.alhewar.com/ISLAMDECL.html; Organisation of Islamic Cooperation, Cairo Declaration on Human Rights in Islam (Aug. 5, 1990); League of Arab States, Arab Charter on Human Rights (Sept. 15, 1994).

34. For more on the relationship between these instruments and Islamic law, see Sadiq Reza, Torture and Islamic Law, 8 CHI. J. INT'L L. 21 (2007).

35. Abdullahi Ahmed An-Na'im, Islam and the Secular State 4, 9-10 (2008) (" $[T]$ he religious beliefs of Muslims, whether as officials of the state or as private citizens, always influence their actions and political behavior," and "[t] he Qur'an and Sunna are ... where Muslims look for guidance in developing their social and political relations, legal norms, and institutions."); Frank Griffel, Introduction, in SHARI'A: IsLAMIC LAW IN THE CONTEMPORARY CONTEXT 1 (Abbas Amanat \& Frank Griffel eds., 2007) ("All normative discussions within Islam, as well as between Muslims and members of other faiths, center on the content of Shari'a."); Kecia Ali, Sexual Ethics in Islam xii (2006) ("For the vast majority of Muslims world-wide-not only extremists or conservatives, but also those who consider themselves moderate or progressive-determining whether a particular belief or practice is acceptable largely hinges on deciding whether or not it is legitimately 'Islamic.' "); FrANK 
tence and application to Islamic criminal law, is far from secure in the current wave of Islamization (and any future one). ${ }^{36}$ Second, the "Islamic" declarations of human rights that follow Western models themselves state that they are subject to definition and qualification by Islamic rules or principles-but they do not list those rules or principles, let alone explain their import. For instance, the UIDHR says that the rights and freedoms it contains are "subject ... to such limitations as are enjoined by the Law," and it defines "the Law" as "the Shari'ah, i.e. the totality of ordinances derived from the Qur'an and the Sunnah and any other laws that are deduced from these two sources by methods considered valid in Islamic jurisprudence." ${ }^{37}$ Citations to the Quran or Sunna for each article appear at the end of the document, in ostensible support, but what rule or principle results from these supporting sources is far from clear. ${ }^{38}$ Similarly, the 1990 Cairo Declaration lists several rights that are familiar in the criminal-procedure context-for instance, personal privacy, presumption of innocence, and freedom from arbitrary arrest-but then says in a short penultimate provision: "All the rights and freedoms stipulated in this Declaration are subject to the Islamic Shari'ah." 39 Nowhere does the Declaration indicate what the sharia says about the rights and freedoms it lists, although it concludes with another short provi-

E. Vocel \& Samuel Hayes III, Islamic Law and Finance 20 (1998) ("Islamic law remainsin faith if not in legal reality-the criterion for right action in Muslim life.").

36. Of course, Muslim-majority countries do not necessarily follow even those criminal procedure rules the legitimacy of which they do not contest. But in that respect they do not differ from non-Muslim-majority countries. See generally Oona A. Hathaway, Do Human Rights Treaties Make a Difference?, 111 YALE L.J. 1935, 1940, 1942 (2002) (finding "not a single treaty for which ratification seems to be reliably associated with better human rights practices and several for which it appears to be associated with worse practices," and concluding that "expressions of commitment to human rights through treaty ratification may sometimes relieve pressure on states to pursue real changes in their policies and thereby undermine the instrumental aims of those very same treaties").

37. Islamic Council of Eur., Universal Islamic Declaration of Human Rights, $2 \mathrm{~J}$. IsLAMIC L. $1,16(1981)$.

38. See id. at 18. For instance, on the "Right to Fair Trial," the citations listed for the five provisions of that article are eight Quranic verses and two unspecified reports from the Sunna. Id. at 9-10. On the two provisions of the article that speak directly to fair trials, the two closest Quranic verses add nothing: one simply tells Muslims to avoid conjecture, 53:28 (in religious matters, no less), and the other instructs them to "ascertain the truth" when a person of bad character (fasiq) reports on others' alleged misbehavior, 49:6. An English translation of the Quran can be found in THE QUR'AN (M.A.S. Abdel Haleem trans., Oxford Univ. Press 2010).

39. Organisation of Islamic Cooperation, supra note 33, arts. 18, 19, $20,24$. 
sion that states that the sharia is "the only source of reference for the explanation or clarification" of the Declaration..$^{40}$

Thus, the existing "Western" templates for criminal procedure are on insecure footing, and neither they nor their "Islamic" restatements tell us what the sharia says on the matter. Moreover, the sharia does indeed discuss criminal procedure-which is the third and perhaps the best reason for identifying "Islamic" rules of criminal procedure. Although no system of criminal procedure appears in the Quran and the Sunna, values, principles, and some specific rules that should apply in criminal procedure-as they do anywhere else in Islamic law and practice-do in fact appear in those texts. ${ }^{41}$ This point is even stronger with respect to classical jurisprudence: although classical Muslim scholars did not articulate a system of criminal procedure, they did set out rules for the process, and they repeatedly invoked the authority of the Quran, the Sunna, and Islamic principles generally in support of these rules. Examples of these rules and principles come in Part III below. The point here is that to enforce Islam's criminal prohibitions and mete out the prescribed punishments without heeding the accompanying procedural rules is arguably to practice Islamic criminal law inaccurately and incompletely-indeed, "unIslamically" - and thus to reach results that might be unjust from an Islamic perspective, even if the standards of Western-inspired rules and principles of criminal procedure are satisfied.

Here a fourth reason might be mentioned, though this one draws its power more from the ideology of human rights than that of Islam (and for that reason, I do not rely on it). In many cases, though certainly not all, the pertinent rules or principles we find in pre-modern Islamic sources and practice actually limit law-enforcement powers in criminal matters-particularly in crimes and punishments of textual provenance-more than the rules and standards of contemporary Western/international practice do. As a result, they are more protective of individual liberties than those

40. Id. art. 25. Hence Ann Mayer observes that the Cairo Declaration and its ilk "[are] ultimaiely more intelligible in terms of the politics of human rights than in.terms of Islamic theology and law," and that the rights contained in them "are not original but are borrowed from international law and then qualified or distorted." Ann Elizabeth Mayer, Islam and Human Rights Policy, in Islam and the Everyday World: Public Policy Dilemmas 66, 69, 71 (Sohrab Behdad \& Farhad Nomani eds., 2007).

41. One well-known example comes in a series of "letters to judges" said to have been authored by Umar ibn al-Khattab, the second successor to the Prophet as leader of the Muslim community. An English translation of the best-known and most pertinent of these letters is in Frank E. Vocel, IsLamic Law and Legal System 15 (2000). 
of contemporary Western/international law. For many, this alone might suffice to justify this inquiry, since an inevitable result should be greater compliance with human-rights norms in Islamic criminal practice.

Still, a likely objection to the project is this: to identify Islamic rules and principles of criminal procedure is to endorse what much of the modern world sees as an inhumane system of crime and punishment, indeed to encourage it. In other words: why not argue against Islamic criminal law as a whole, rather than propose adjustments to its practice? My response is two-fold. First, to question the theory or practice of Islamic criminal law is nothing new; prominent Muslim voices have long done this, and they continue to do so. ${ }^{42}$ Second, Muslims who practice or advocate Islamic criminal law deeply and genuinely believe in that law as a divine mandate. ${ }^{43}$ To challenge that belief-for one's starting point to be the denial of what many Muslims believe God and the Prophet ordained about crime and punishment in, respectively, the Quran and the Sunna (not to mention the rejection of fourteen hundred years of venerated literature on the matter)-is to close the ears of these Muslims before one has begun speaking. ${ }^{44}$ In other words, the commitment to Islamic criminal practice among Muslims-not all Muslims, but certainly those who urge or support that practice-is unshakeable, for present purposes at least, and it must be seen that way and addressed accordingly. Stated differently: arguments from within the Islamic tradition, not arguments against that tradition, are necessary if one wishes to reach an audience of devout Muslims..$^{45}$ Nor, accordingly, can arguments from within the Islamic tradition be easily dismissed, whatever one's purpose in

42. For two of the most authoritative efforts in modern times, see Fazlur Rahman, The Concept of Hadd in Islamic Law, 4 IsLamic STud. 237 (1965) (arguing against the standard juristic classification of hudud as criminal punishments); Tariq Ramadan, An International Call for Moratorium on Comporal Punishment, Stoning, and the Death Penalty in the Islamic World, TARIQ RAmadan (Apr. 5, 2005), http://tariqramadan.com/blog/2005/04/05/an-interna tional-call-for-moratorium-on-corporal-punishment-stoning-and-the-death-penalty-in-the-is lamic-world (calling for a moratorium on hudud punishments and urging scholarly discussion of their textual and contextual grounds).

43. See supra note 35 .

44. See, e.g., Tariq Ramadan, A Call for a Moratorium on Corporal Punishment - The Debate in Review, in New Directions in Islamic Thought: Exploring Reform and Muslim TradiTION 163, 164 (Kari Vogt et al. eds., 2009) (discussing his 2005 call and Muslim reactions to it); Tarie Ramadan, Radical Reform: Islamic Ethics and Liberation 274-77 (2009) (same, in less detail).

45. Naz Modirzadeh puts it well; criticizing what she deems the failure of international human-rights organizations (INGOs) to engage appropriately with Islamic law in their analysis and reports as follows: 
presenting them-hence this effort to identify the procedural rules and principles that Islam itself provides to govern criminal practice.

There are many sources in which to seek such rules and principles. The starting-point is of course the Quran and the Sunna: as explained below, statements that bear on criminal procedure appear in both of these sacred sources, and numerous reports in the Sunna of criminal matters from the Prophet's time add pertinent precedents for modern practice that are especially authoritative. Additional venerated sources from the early centuries of Islam are codes of conduct for judges ( $a d a b$ al-qadi), manuals to guide inspectors of markets and morals (muhtasibs), collections of legal opinions (fatwas), and miscellaneous other legal literature. ${ }^{46}$ Among this pre-modern literature are the monographs and treatises of jurists whose names remain as familiar, and their writings as influential, to Muslims today as the names and writings of Franklin, Jefferson, and Madison are to Americans today-al-Ghazzali, alMawardi, Ibn Taymiyya, and Ibn Farhun, to name a few. Modern times too are a resource: rich material lies in the statutes and jurisprudence of some of the countries that practice Islamic criminal law today, material that remains mostly unexplored in the West. ${ }^{47}$ And the efforts by contemporary Muslim thinkers to address aspects of criminal procedure from an Islamic perspective, mentioned above, are yet another resource, as are the "Islamic" humanrights instruments mentioned above.

Current INGO approaches risk creating situations in which Muslims must decide to either side with human rights or to side with God. Whatever its intrinsic appeal, international human rights law is unlikely to be favored in this ultimatum.

....

[W] hen their choice is framed as an either/or, many Muslims may believe that they have no option but to choose God's law.

Naz K. Modirzadeh, Taking Islamic Law Seriously: INGOs and the Battle for Muslim Hearts and Minds, 19 Harv. Hum. Rts. J. 191, 230-31 (2006). See also supra note 35.

46. For examples and discussions of these types of literature, see, e.g., Muhammad Ibrahim H.I. Surty, The Ethical Code and Organised Procedure of Early Islamic Law Courts, with Reference to al-Khassaf's Adab al-Qadi, in CRIMINAL Justice IN IsLAM: Judiclal Procedure IN THE SHARI'A, supra note 13, at 149, 150 (discussing al-Khassaf's Adab al-Qadi and citing counts of between 63 and 121 such judicial codes extant); ABD AL-RAHMAN B. NASR ALShayzari, The BoOK of THE Islamic MARket InsPector (R.P. Buckley trans., Oxford Univ. Press 1999) (1946) (a muhtasib manual); Muhammad Khalid Masud et al., Muftis, Fatwas,

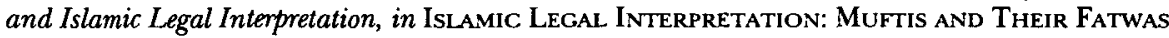
3 (Muhammad Khalid Masud et al. eds., 1996) (discussing fatwas).

47. For an excellent resource on modern sharia criminal practice in Nigeria, see 4, 5 Philip Ostien \& Ibrahim Na'tya Sada, Sharia Implementation in Northern Nigeria 1999-2006 (2007). 
An overarching theoretical framework for the inquiry may be found in the quintet of interests that Muslim jurists have long recognized as the fundamental goals of the sharia. Articulated in various formulations by classical jurists, i.e., by the fourteenth century $\mathrm{CE}$, and still invoked regularly today, these are "the five essentials" or "interests" (al-daruriyat or al-masalih al-khamsah) of the sharia: the protection of religion, life, intellect, reputation (or honor or lineage), and property. ${ }^{48}$ These interests are already used to explain and encapsulate specific doctrines or bodies of Islamic law, including the list of crimes that God saw fit to specify in the Quran and the Sunna-the hudud. Indeed, it is from the hudud that these interests are said to have been originally identified. ${ }^{49}$ There is thus every reason to employ them to articulate and embrace the rules and principles of criminal procedure that can be identified in the sacred texts and the jurisprudence that builds on them..$^{50}$

One more point needs elaboration before turning to the sources to identify specific rules and principles of "Islamic" criminal procedure. My claims here ultimately are normative ones in the premise of this inquiry-i.e., that such rules and principles should be recognized and honored-and in its results. That is, my goal is to identify those rules and principles that the sources indicate are aspects of "proper" Islam-normatively desirable expressions of the religion. But the search for these norms spans sources that include historical reports and normative assertions. This is because normative authority in Islamic law lies as much in historical practice-reports in the Sunna, most prominently-as it does in sources of more theoretical or expressly didactic bent, like the Quran or jurists' treatises. More important than distinguishing between normative and historical grounds for a claim is identifying its source. Who provides the authority-God (in the Quran), the Prophet, a Companion or early jurist, or someone else? When did it come-in the Prophet's time (most authoritative), or some time later? In what

48. See Mohammad Hashim Kamali, Law and Ethics in Islam: The Role of the Maqasid, in New Directions in Islamic Thought: Exploring Reform and Muslim Tradition, supra note 44 , at $23,27-28$. There are various formulations of this list, especially as to the fourth of these five interests. Additions to the list have also been suggested, particularly in modern times. See, e.g., id. at 43-44; Gudrun Kramer, Justice in Modern Islamic Thought, in Shari'a: Islamic Law IN the Contemporary Context, supra note 35, at 20, 23-34.

49. See Kamali, supra note 48 , at 27.

50. Care must, of course, be taken not to stretch or apply these articulations, or any of their constituent concepts, in such a way as to make them foreign to their original contexts and meanings, or to use them merely as heuristic devices through which to claim an Islamic pedigree for rules and principles that arguably have none. For a careful and wellresearched warning in this regard, see Kramer, supra note 48 , at 36-37. 
context did it arise-for our purposes: in an actual criminal case, in a discussion of state power or religious authority, or in some other context? Sources of all types and times can constitute or provide normative authority in Islam, for this inquiry as for any other. Ultimately, however, it is for Muslims to decide-individually and collectively, according to what they find authoritative-what the religion commands, urges, discourages, or prohibits.

\section{A Starting Point: Four Principles}

This Part begins the task of identifying rules and principles of due process that the Quran, Sunna, and classical jurisprudence set out to govern the enforcement of the criminal prohibitions and penalties that those same sources specify. Four such rules or principles are discussed here, each bearing on a discrete aspect of the criminal process chronologically and conceptually. These aspects are: (1) investigation, which encompasses searches and seizures, interrogations, and other methods state officials employ to detect crime, identify suspected offenders, and collect evidence; (2) prosecution, which includes deciding what criminal charges to bring against an alleged offender and formally proceeding with those charges; (3) adjudication, which means the process of reaching a verdict according to evidence (facts) introduced at trial and the governing legal rules; and (4) imprisonment, which can be a form of punishment but can also occur before an offender is convicted (i.e., pretrial detention). For each of these aspects, the rule or principle discussed has been selected because of its prominence in the classical sources and its representativeness as a rule that bears on enforcing Islam's criminal prohibitions and penalties but appears to be ignored today. No single theme fully unites the list that follows, but one common thread stands out and perhaps predominates: how many obstacles are erected to investigating, prosecuting, and punishing a person for violating any of the most serious of sharia crimes (i.e., the hudud).

\section{A. Investigation: Honor Privacy}

From two simple rules in the Quran, several related reports in the Sunna, and pertinent doctrines classical jurists derived from these rules and reports, this maxim emerges clearly: personal privacy must be honored in the process of detecting crime and investigating criminal suspects. This principle restrains private citizens as well as state officials, and it is to be followed even when that means forgoing an investigation, and thus permitting a crime to go 
unprosecuted and unpunished; indeed, even when it means allowing criminal behavior that is underway to continue. The Quranic rules are simple: "Enter not houses other than your own, until you have asked permission and saluted those in them," and "[s]py not on each other." 51 The Sunna repeats and elaborates on these rules in several reports. For example, regarding the "enter not without permission" verse, the Prophet specifies appropriate and inappropriate methods of satisfying the permission requirement, as well as exceptions to the requirement and possible penalties for violating it.52 Regarding the "spy not" verse, the Prophet restates and expands on the command, and provides examples of the forbidden act-for instance, eavesdropping and reading others' correspondence-and again suggests possible penalties for non-compliance. ${ }^{53}$

Respect for the personal privacy of fellow Muslims is the thrust of these commands; this is evident in commentary about the cited Quranic verses that one finds in works of tafsir (exegesis) and asbab al-nuzul ("occasions of revelation"), and it is self-evident in the Sunna reports. ${ }^{54}$ Other Sunna reports also make it clear that the commands apply in criminal investigations as much as anywhere else, and that their effect is to restrain state officials in those investigations. ${ }^{55}$ The best known of these reports involve Umar ibn alKhattab, the second leader (caliph) of the Muslim community after the Prophet's death. ${ }^{56}$ Three separate anecdotes in the Sunna depict Umar as declining to act on wrongdoing; specifically, wine drinking and accompanying revelry he witnesses by entering the wrongdoers' homes without permission and surreptitiouslythereby violating the Quran's "enter not" and "spy not" commands. ${ }^{57}$ Another report from the Sunna suggests a principle that emerges from this authority and unites/animates it. Ibn Mas'ud, another Companion of the Prophet, when told that a certain person's beard was "dripping with wine," reportedly said: "We have

51. Qur'an 24:27, 49:12. The first verse is followed by Qur'an 24:28, which continues as follows:

That is best for you, in order that you may heed (what is seemly). If you find no one in the house, enter not until permission is given to you; if you are asked to go back, go back. That makes for greater purity for yourselves, and God knows well all that you do.

52. Reza, supra note 16 , at 724 .

53. Id. at 724-25.

54. See id. at 792-95.

55. See id. at 749-50.

56. See id. at 725 .

57. Id. at 725-27. 
been prohibited from seeking out [others' faults]; but if something becomes manifest to us, we can seize it." 58 In other words, wrongdoing that is committed openly may be pursued; but wrongdoing that is not may not.

Classical jurists accordingly articulated doctrines of restraint in criminal investigation based on this principle. These doctrines typically appear in discussions of the duties and powers of an official called the muhtasib, whose job was to walk the streets of Muslim cities to police residents' markets and morals. ${ }^{59}$ Two of the best known of these discussions are in works by al-Ghazzali and alMawardi. ${ }^{60}$ Both discussions invoke the Quranic and Sunna texts above (along with others) to set limits on the muhtasib's investigative powers, beginning with a rule that echoes Ibn Mas'ud's statement in the Sunna report above: the muhtasib may not act on wrongdoing that is not public or "manifest" (zahir)-i.e., wrongdoing that is apparent without entering a home or spying. ${ }^{61}$ This rule has corollaries as well as exceptions. One corollary is that the muhtasib may not seize or search suspected wrongdoers themselves without a specified quantum of individualized suspicion-a "particular sign" of guilt ('alamah khassah), in al-Ghazzali's formulation. ${ }^{62}$ Another is that homes in which wrongdoing is suspected may not be entered as long as evidence of the wrongdoing-the sounds of drunken revelry, for instance-does not travel outside of the home. ${ }^{63}$ One exception, meanwhile, is that the muhtasib may enter a home if, in al-Mawardi's version, there is "indicative evidence" (amarat dallat) that a serious crime such as adultery or homicide is underway. ${ }^{64}$ But beneath this threshold (which is stated somewhat differently in al-Ghazzali's formulation), ${ }^{65}$ and from other statements about the muhtasib's powers in these works and others, the message is clear: muhtasibs are generally forbidden to intervene in the private lives of fellow Muslims, even to enforce the religious prohibitions that are central to their duties.

58. Id. at 725. This apparently meant that the drinker and his drink were to be left alone because no one had witnessed the act of drinking. See id. at 789.

59. Id. at 733.

60. See Al-Mawardi, The Ordinances of Government 260-80 (Wafaa H. Wahba trans., Garnet 1996). Unfortunately, a reliable English translation of the relevant chapter of al-Ghazzali's work does not appear to be available. See Reza, supra note 16, at 737 n.106.

61. Reza, supra note 16, at 737; see AL-MAWARDI, supra note 60, at 260, 273.

62. Reza, supra note 16 , at 739 .

63. Id.

64. AL-MAWARDI, supra note 60, at 273.

65. Reza, supra note 16 , at 738 . 


\section{B. Prosecution: Forgo Instead}

Several reports in the Sunna reflect a preference that hudud crimes-for all their seriousness, and even if they satisfy the "manifestness" requirement discussed above-not be prosecuted at all. ${ }^{66}$ Statements of this preference are directed especially toward citizens who know of hudud violations, including citizens who were personally harmed by them. ${ }^{67}$ One report to this effect describes the Prophet as first laboring to avoid hearing a confession of adultery by a young man named Ma'iz, then regretting having to punish him, and finally chastising those who sent Ma'iz to him in the first place. ${ }^{68}$ There are various versions of this report, and the details of the Prophet's exchange with Ma'iz vary. ${ }^{69}$ But in most versions, the Prophet repeatedly turns away from Ma'iz when he comes to him to confess, evidently giving Ma'iz the opportunity to abandon the enterprise and return home. One version even has the Prophet cross-examining Ma'iz with suggestions that he might be mistaken about his own guilt: "Perhaps you [only] kissed, or squeezed, or looked?"7o But Ma'iz persists, and after he has confessed four times-and thus matched the number of witnesses required to prove the hadd crime of adultery-the Prophet finds Ma'iz guilty and accordingly orders him to be stoned to death. ${ }^{71}$ The Prophet then turns to the person who urged Ma'iz to come to him and says: "If you had covered him with your garment, it would have been better for you."72 In other words, the fellow Muslims should have kept Ma'iz's wrongdoing to themselves, rather than pushing Ma'iz to be adjudicated, found guilty, and punished. ${ }^{73}$

Another report in this vein tells us that one of the Prophet's Companions, Safwan ibn Umayyah, brought a man to the Prophet for adjudication and punishment for stealing Safwan's cloak. ${ }^{74}$ The Prophet found the man guilty and ordered the hadd punish-

66. See, e.g., Aliu Dawud, Kitab Al-Hudud [Prescribed Punishments] book 38, no. 4405 (Ahmad Hasan trans., Ctr. for Muslim-Jewish Engagement), available at http://www .usc.edu/org/cmje/religious-texts/hadith/abudawud/038-sat.php.

67. See id.

68. Id.

69. Compare id., with id. no. 3643.

70. Id. no. 4413.

71. Id. no. 4412.

72. Id. no. 4364.

73. See id. In a similar report, a man caught for theft admitted the crime, but had none of the stolen goods. Id. no. 4367. When he was brought to Prophet Muhammad, the Prophet expressed doubt about his guilt until the man repeated his confession. Id.

74. Al-Tirmidhi, Hadith 1020 (Alim.org), available at http://www.alim.org/library/ hadith/TIR/1020. 
ment of amputating the man's hand. ${ }^{75}$ Before the amputation, Safwan implored the Prophet to remit the punishment, and the Prophet's response was: "Why did you not do [this intercession] before bringing him to me?"76 The Companions apparently learned this lesson well.

Yet another report along these lines involves a different Companion, Uqba ibn Amir al-Juhani, who served as a governor in Egypt. ${ }^{77}$ Uqba's secretary told the governor he had neighbors who drank wine-another hadd crime-and proposed summoning the police to arrest them. ${ }^{78}$ Uqba told the secretary not to do that, but rather to "counsel" and "threaten" the neighbors to amend their conduct. ${ }^{79}$ The secretary complied; but the neighbors continued their wrongdoing, so the secretary again proposed calling the police. ${ }^{80}$ Uqba rejected the idea again, and this time quoted a tradition he had heard from the Prophet: "He who sees something which should be kept hidden and conceals it will be like one who has brought to life a girl buried alive." 81

These anecdotes, taken together, stand for the proposition that, for at least three of the hudud crimes-wine-drinking, theft, and adultery, which carry penalties of flogging, amputation, and stoning to death, respectively-forgoing prosecution is urged, on the authority of the Prophet himself. To be sure, an opposite principle also traces back to the Prophet, but its reasoning arguably strengthens the point. The Prophet said, "Forgive the hudûd in what is your affair; for whatever hadd reaches me is obligatory." ${ }^{2}$ "The Prophet himself could not disregard hudud crimes, since punishing for them is a right of God (haqq Allah), and he was God's viceregent on earth; but for that very reason, fellow Muslims should avoid bringing them to his attention. ${ }^{83}$ Similarly, wrongdoers should not turn themselves in for prosecution; better they keep

75. Id.

76. Id.

77. See Abu Dawud, Kitab Al-Adab [Gieneral Behavior] book 41, no. 4874 (Ahmad Hasan trans., Ctr. for Muslim-Jewish Engagement), available at http://www.usc.edu/org/ cmje/religious-texts/hadith/abudawud/041-sat.php.

78. See id.

79. Id.

80. Id.

81. Id. nos. $4873,4874$.

82. VOGEL, supra note 41 , at 243.

83. See id. Still, there are also reports that suggest the opposite. For instance, "[w]hoever with his intercession prevents one of the hudûd of God opposes God in His affair," id. at 242 (quoting Abu Dawud), and "[f]orgive the people of good qualities their slips, but not faults to which prescribed penalties apply," Dawud, supra note 66, no. 4362. 
their peace and repent: "Let whoever attempts any of this rubbish [i.e., prohibited acts] hide himself from view as God admonished," said the Prophet, "for those who reveal themselves to us will have God's penalties enforced against them." 84 Officials, then, might have to prosecute hudud crimes and punish offenders to effectuate God's wishes; but for that very reason, citizens are urged not to bring hudud violations by their fellow Muslims to officials' attention.

\section{Adjudication: "Avoid the Hudud"}

Even when hudud crimes are prosecuted, another legal principle stands in the way of convicting defendants of them and meting out the commensurate punishments. Jurists since the earliest centuries of Islam have quoted the Prophet as having said, "[a]void [the hudûd punishments] in cases of doubt or ambiguity." 85 This instruction not only echoes the advice to forgo hadd prosecutions, but both impels and summarizes a host of procedural obstacleslegal presumptions, rules of evidence, testimonial hurdles, and more-to reaching verdicts of guilt when those prosecutions are undertaken. For instance, according to this principle, when adjudicating a hadd crime, the judge (qadi) must scrutinize the case for any factual or legal "doubt" (shubhah) as to the defendant's guilt, for the very purpose of "seek[ing] a pretext to prevent punishment." 86 Any failure of the elements or evidence of the crime bars the hadd conviction and punishment (although discretionary and lesser ta'zir punishments might still be applicable).$^{87}$

In a prosecution for adultery, for example, such a failure of proof might lie in the following: intercourse that is other than vaginal, since the Quranic proof requires that the adultery be of the type that could produce offspring; 88 a defendant's mistaken belief that intercourse was lawful-i.e., the parties' marriage proves technically deficient, or their divorce is complete but the defendant thought otherwise; ${ }^{89}$ and accusations that are not lodged within a

84. Al-Mawardi, The Ordinances of Govirnment 260-80 (Wafaa H. Wahba trans., Garnet 1996).

85. Various versions of the statement have been reported and adopted by most schools of Islamic law; but the prophetic pedigree of each version is apparently weak or nonexistent. See Intisar A. Rabb, Islamic Legal Maxims as Substantive Canons of Construction: Hudud-Avoidance in Cases of Doubt, 17 IsI AMIC L. \& Soc'y 63, 65-67 (2010).

86. The Hedaya 176 (Charles Hamilton trans., 1870, Islamic Book Trust 1982).

87. See, e.g., id. at 184.

88. See id. at 185.

89. See id. at 182-84. 
specified period of time, since delay raises doubts about the motives of the accusers, and thus about a standard requirement of witness testimony: the witnesses' moral probity (adalah). ${ }^{90}$ Should four witnesses qualify to testify, ${ }^{91}$ factual inconsistencies among their testimony-regarding, for instance, the location of the alleged act of unlawful intercourse, or the identity of the defendant's partner-raise doubt sufficient to preclude hadd punishment. ${ }^{92}$ And of course, if the testimony of one of the necessary four witnesses is inadmissible or legally insufficient, the remaining three witnesses are liable for punishment of the hadd crime of qadhf, false accusation of adultery. ${ }^{93}$ Similarly, a defendant's confession to adultery, which may substitute for the requisite four witnesses, must be given four times in four separate sessions to better identify any factual or legal insufficiency in the testimony. ${ }^{94}$ Even after that, the hadd penalty must be withheld if the defendant retracts his confession, since the retraction creates doubt as to his guilt. 95

The same or similar rules govern adjudicating other hadd crimes, with examples of factual or legal doubt tailored accordingly. ${ }^{96}$ And lest there be any doubt that the principle, and the many rules that embody it, aim specifically at avoiding hudud punishments-that it reflects and commands a genuine aversion to inflicting the most serious of God's criminal penalties, rather than simply cautions prudence in adjudicating hadd crimes-consider this additional language that is found in one version of it: "It is better for the ruler (imam) to err in pardon than to err in punishment." 97 A mistaken acquittal, in other words, is preferable to a mistaken conviction and punishment, at least when it comes to hadd crimes. Surely, it is the very harshness of hadd punishments that commends this corol-

90. See id. at 188-89. A routine inquiry into witnesses' moral probity should always be conducted in secret as well as in public, in order to better uncover character flaws that would nullify a witness's testimony. See id. at 176 . The reason being is that if a defendant is punished with hadd, and thereafter one of the supporting witnesses is discovered to have had insufficient moral probity to have properly permitted his testimony, the state or the court-appointed "character investigator" (muzakki) who declared the witness qualified is liable to the defendant for damages. See id. at 191, 193.

91. Four witnesses are requisite to substantiate a conviction for adultery. See id. at 176 .

92. See id. at 190.

93. See id. at 191 .

94. See id. at 177.

95. See id. at 178.

96. See, e.g., id. at 195-97 (wine drinking); id. at 197-203 (false accusation of adultery); $i d$. at 205-13 (theft).

97. See Vockl, supra note 41 , at 243. 
lary principle. ${ }^{98}$ Thus, when it comes to the most serious transgressions of God's law, Muslim jurists have spent the better part of fourteen hundred years urging qadis (judges) and imams (leaders) to find reasons to avoid convicting and punishing alleged offenders.

\section{Punishment: Routinely Question All Prisoners to Determine the Lawfulness of Their Detention}

Imprisonment is not among the hadd penalties in the classical template of Islamic criminal law. Rather, it is a discretionary punishment ( $t a$ 'zir) that is available when proof of a hadd crime fails, or criminal conduct falls outside of hadd categories. ${ }^{99}$ Detention is also authorized before trial, in most views, for interrogation or simply to hold defendants until their cases are adjudicated. ${ }^{100}$ Also, outside of criminal cases-in pre-modern times in Muslim lands and elsewhere-individuals could be imprisoned for the non-payment of debts. ${ }^{101}$

Whatever the rationale for imprisonment, those who were imprisoned received special attention from classical Muslim jurists, most notably in a rule that apparently originated with the Hanafi jurist al-Khassaf. ${ }^{102}$ Upon assuming office, al-Khassaf said in his Adab al-Qadi (Rules for the Judge), every qadi must visit the prisons, record the names of inmates and the dates of their imprisonment, and inquire into the reason for each inmate's imprisonment. ${ }^{103}$ The qadi must ask each inmate himself why he is detained, and if any inmate claims his imprisonment is unlawful, the qadi must investigate further. ${ }^{104}$ This is, of course, an extraordinary version of what Anglo-American law knows as the writ of habeas corpus. ${ }^{105}$ Unlike that writ, however, the inquiry in the Islamic context is considered a routine requirement of every new judge, with respect to every prison inmate. Indeed, so central is it to the judicial function

98. It is hard to avoid mentioning the analogous principle in Anglo-American law, indeed perhaps the most famous aphorism of that law-namely, Blackstone's: "It is better that ten guilty persons escape, than that one innocent suffer." See 4 William Blackstone, CommentaRies *352.

99. VOGEL, supra note 41 , at $247-48$.

100. Reza, supra note 16 , at $752-59$.

101. Irene Schneider, Imprisonment in Pre-Classical and Classical Islamic Law, 2 IsLAMIC L. \& Soc'y 157, 165 (1995).

102. See Imam Khassaf, Adab al-QAdi [Rules for the Judge] 128-39 (Munir Ahmad Mughal trans., Adam Publishers \& Distributors 2005) (in English).

103. See id. at $128-29$.

104. See id. at 128-33.

105. See U.S. Const. art I., $\S 9$, cl. 2 ; 28 U.S.C. $\$ \S 2241,2254$ (2006). 
in Islamic jurisprudence that the Shafi'i jurist al-Nawawi, in his Minhaj et Talibin, lists it as the very first thing a new qadi should do upon assuming office. ${ }^{106}$

Of course, the sources yield many other rules and principles that bear on the criminal process, and not all of them are limits. Nor are the four discussed above absolute in any sense; for each, there is also authority to the contrary. ${ }^{107}$ There is also no claim that any of them has been routinely practiced in the hundreds of years since they were set out by God, the Prophet, his Companions, or any classical jurist. But that is precisely the point: due process rules and principles found in the Quran and the Sunna might be ignored in the contemporary practice of Islamic criminal law in part because they went unrecognized and unpracticed over the lands and centuries of Islam-lands and centuries in which, for Muslims and for the rest of the world, power rather than principle defined and shaped the everyday exchange between rulers and their subjects, whatever religious scholars and others had to say about that exchange.

The goal of this inquiry is thus to re-introduce these rules and principles to sharia scholars and practitioners, with pertinent authority. Further works of various kinds must follow-to add to the list, as well as to explore further those already on the list; to search the historical record for evidence of the practice vel non of these rules and principles; to explore whether they are honored today in the countries that claim to practice Islamic criminal law; and most importantly, to make them so honored. Meanwhile, some observations on the findings above are in order.

\section{Observations}

Suggested in the first three of the rules or principles presented in Part III is a general aversion toward investigating, prosecuting, and punishing individuals for hadd crimes. ${ }^{108}$ And the fourth rule reflects an awareness of the ever-present possibility-indeed the inevitability - of instances of unlawful imprisonment and a staunch commitment to minimizing their occurrence and length. Together, the four show a great wariness of criminal proceedings

106. Nawawi, Minhaj et Talibin: a Manual of Muhammadan Law According to the School of Shafi 503-04 (E.C. Howard trans., W. Thacker \& Co. 1914).

107. See supra note 83.

108. See supra Part III. 
in general and several discrete components of them in particular: the exercise of official power in applying them, the behavior of private parties in initiating them, and the punishment of individuals pursuant to them.

Such a wariness of official judgment pervades Islamic literature on legal proceedings. "One who is appointed qâdî is as slaughtered without a knife," goes a well-known prophetic Tradition, and another one elaborates: "Qâdîs are three: two in the Fire, and one in Paradise." 109 Even judging well does not protect a Muslim unfortunate enough to be in the position of doing it: "The just qâdî will be brought on the Judgment Day, and confronted with such a harsh accounting that he will wish he had never judged between any two, even as to a single date." 110 Little wonder then that some early Muslim legal scholars reportedly went to great lengths to avoid formal judicial appointments, especially as the office became increasingly subject to control by political authorities. ${ }^{111}$ It is even less wonder that jurists articulated doctrines and principles like the third of those presented above ("avoid the hudud"), which makes it difficult to convict individuals of hudud crimes, and the fourth ("question all prisoners"), which ensures regular opportunities to correct erroneous imprisonment. Nor are these the only examples of such jurist-generated doctrines. ${ }^{112}$

But the wariness of judgment in Islamic criminal law does not begin with jurists; rather it originates with God and the Prophet, in the Quran and the Traditions. It is the Traditions that underpin the second principle illustrated above ("forgo prosecution"); and the Quran precedes them in establishing the first one ("honor privacy"). The Quran even repeatedly commends forgiving hadd offenders who repent, rather than meting out the prescribed punishments, often in the very verses in which it prescribes those punishments. ${ }^{113}$

Why would the Quran encourage forgoing the very punishments it sets out for crimes, and the Prophet in turn discourage even

109. Vogel, supra note 41 , at 20.

110. Id. at 19-20 (emphasis added).

111. See N.J. Coulson, Doctrine and Practice in Islamic Law: One Aspect of the Problem, 18 Bull. Sch. Oriental \& African Stud. 211, 211-12, 218-19 (1956).

112. See The HedAYA, supra note 86 , at 353-59 (discussing doctrines related to evidentiary burdens).

113. Qur'an 5:33-34 (remitting punishment for committers of mayhem who repent); Qur'an 5:38-39 (same for thieves); Qur'an 24:4-5 (false accusers); see also Qur'an 25:68, 25:70 (remitting divine punishment for idolaters, murderers, and adulterers who repent before death). 
investigating and prosecuting individuals for those crimes, even as he adjudicated such cases and punished offenders accordingly? Why announce the crimes and punishments at all, then? One answer is that God did not mean for the hudud to be prosecuted by authorities at all-i.e., that they are not really crimes. A more conventional answer is that God announced the hudud as deterrents, but wanted convictions and punishment to be few and far between, given the severity of the penalties and the ever-present possibility of erroneous conviction. Yet another possible explanation for these procedural rules and principles that have the effect of hindering criminal proceedings is that they serve to protect other values that might too easily be forsaken in the zeal to prosecute and punishprivacy and dignity, for instance-or to promote other social ends, such as (perhaps) a culture of resolving disputes privately or among the community rather than by bringing them to the attention of authorities. Or perhaps the explanation is a divine purpose that the believing Muslim cannot discern. Nevertheless, whatever the rationale for these rules and principles, it is certainly not vindicated when a state enforces Islamic criminal law without heed for the duty of restraint these commands suggest.

It also bears noting that the rules and principles discussed above exceed Western standards in limiting official powers in criminal law-enforcement. For instance, nothing like a "presumption of non-prosecution" is a typical feature of modern (Western) criminal procedure, although there are grounds for reduced sentences and other forms of leniency in certain circumstances. ${ }^{114}$ As for the muhtasib, rules that govern when and how law-enforcement officials may investigate suspected wrongdoing are certainly a central feature of Western criminal procedure; such rules are the focus of, for instance, the Fourth Amendment to the U.S. Constitution. ${ }^{115}$ But forbidding the investigation of "private" wrongdoing is not typically among those rules. Nor is the requirement that jails and prisons be routinely visited to confirm the lawfulness of each inmate's detention.

This does not mean that all rules and principles of the criminal process that can be found in the primary sources and the jurisprudence of Islamic law will point in the "protective" direction sug-

114. There are, however, grounds for reduced sentences and other forms of leniency in certain circumstances. See, e.g., U.S. ConST. art II, \$2, cl. 1 (presidential pardon power); 18 U.S.C. $\$ 3607$ (2012) (authorizing probation and expungement procedures for firsttime drug possessors); U.S. Dep't of Justice, U.S. Attorney Manual ch. 9-22.000 (authorizing probation instead of prosecution for qualifying offenders and offenses).

115. See U.S. Const. amend. IV. 
gested in the above illustration, or that they will necessarily comport with modern (Western) sensibilities. On the matter of investigative torture, for instance, some reports in the Sunna arguably authorize that abhorrent practice (while others appear to forbid it), and some influential classical jurists-al-Mawardi among them-declared the practice acceptable in at least some criminal investigations, while others deemed it forbidden. ${ }^{116}$ But the possibility that Islamic rules or principles of criminal procedure might be repugnant to modern sensibilities does not seem a good reason to avoid identifying them. Even if it were, all indications, I admit I am happy to report, are that the rules and principles one finds typically meet or exceed the protective standard of contemporary Western rules. This Article illustrated three examples; others include the presumption of innocence, the right of a defendant to retract a confession, and the requirement of the equivalent of proof beyond a reasonable doubt for conviction. In the end, the Islamic crimes and punishments at issue are themselves repugnant to modern sensibilities; but we must grapple with them nonetheless.

116. See Reza, supra note 34, at 24-25. 
